\title{
Coronavirus Disease (COVID-19): Challenges and Opportunities
}

\author{
Gholamreza Farnoosh, PhD; Gholamhossein Alishiri, PhD; Alireza Jalali Farahani, PhD; \\ Nasirudin Javidi, PhD; Zahra Farhangi, MA; Mohammadkarim Bahadori, PhD (1); \\ Ramin Ravangard, PhD
}

$\mathrm{S}$ ince December 2019, the world health care community has faced the 2019 coronavirus disease (COVID-19) outbreak caused by severe acute respiratory syndrome coronavirus 2 (SARS-CoV-2). ${ }^{1}$ Coronavirus is a large family of viruses that can cause respiratory infections ranging from the common cold to more severe illnesses such as the Middle East respiratory syndrome 2 (MERS) and Severe Acute Respiratory Syndrome (SARS). The outbreak of this new virus began in December 2019 in Wuhan, China. ${ }^{2}$ The virus seems to be extremely contagious and has rapidly spread throughout the world. ${ }^{3}$ The virus is a submucosal infectious agent that only multiplies in the living cells of an organism. There are different types of viruses. They can infect animals, plants, and microorganisms, including bacteria and the ancients. ${ }^{4}$

MERS is also a viral respiratory disease that was first reported in Saudi Arabia in 2012 and has spread to several other countries. Moreover, SARS is a viral respiratory disease caused by a coronavirus called the coronavirus associated with SARS (SARS-CoV). ${ }^{5}$

The virus that causes COVID-19 is easily spread in areas where there is a living cell. This local spread means that people may be directly infected with the virus or they can be carriers of it. ${ }^{5}$

As far as research is concerned, leading scientists are looking for the treatment of COVID-19. In Iran, the Baqiyatallah University of Medical Sciences has started a large scientific research on the rapid diagnosis, vaccine, and drug discovery with the help of a team of physicians and researchers and has achieved promising results, so far.

\section{CHALLENGES}

The virus transcended China's borders very quickly and spread to 212 countries by May 5, 2020. This process is called human-to-human transmission, which contributes to the virus spread and expansion. ${ }^{6}$ The countries with the highest prevalence of COVID-19 confirmed by the World Health Organization (WHO) include China,
United States, Italy, Spain, Germany, France, Iran, and the United Kingdom. With the rapid global spread of COVID-19, which has affected 212 countries worldwide by May 5, 2020 (3 659103 people affected, 252573 deaths, and 1203404 persons recovered), the world is getting closer to the pandemic of COVID-19 more than ever (Figure 1).

The symptoms of the virus vary from mild to severe. Its symptoms include fever, cough, and difficulty with breathing. ${ }^{7-10}$ Anxiety is also considered a psychological symptom and a common symptom in patients with chronic respiratory disorders and can significantly reduce patients' quality of life. ${ }^{11-13}$

Little research has been conducted on the experience of anxiety in patients with COVID-19. ${ }^{14}$ In fact, anxiety in such patients is mostly due to the unknown disease and the cognitive ambiguity of people about the virus that this anxiety can also disrupt the lives of families and couples. ${ }^{15-17}$ Fear of the unknown reduces the perception of immunity in humans and has always been a source of anxiety for mankind. The lack of scientific information about COVID-19 also exacerbates this anxiety. ${ }^{18,19}$ Therefore, stress and anxiety can weaken the immune system. ${ }^{20,21}$ As a result, people should learn strategies and skills to cope with anxiety, which can enhance human empowerment. Given the rapid spread of the disease, research with regard to the prevention and treatment is needed to improve people's quality of life and community health. ${ }^{22-24}$ The feeling of insecurity caused by anxiety is treated with psychotherapeutic approaches such as emotionally focused therapy. ${ }^{25,26}$

\section{OPPORTUNITIES}

This virus, along with the damages it has caused, also provided opportunities for people to develop their existential and skill-building capacities and has led to achievements such as upgrading hardware and software capacities, improving the knowledge of specialists, adhering to health and hygiene principles by the general public, enhancing the spirit of empathy between people and authorities, understanding the importance 


\section{FIGURE}

\section{The Prevalence of COVID-19 in Countries Around the World by March 25, 2020 (newatlas.com).}

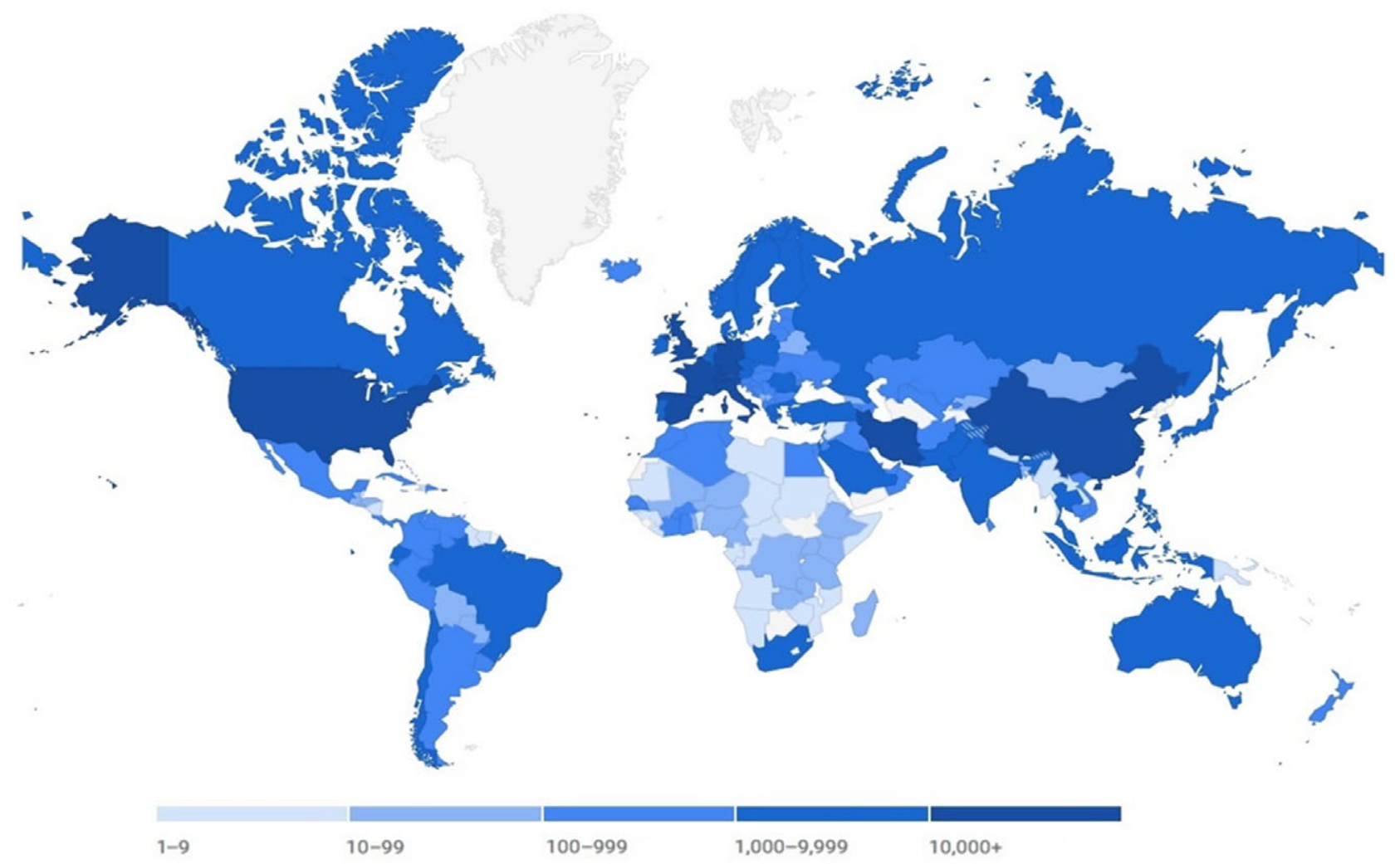

of the medical staff's efforts, publishing scientific articles and reaching the boundaries of knowledge, identifying strengths and weaknesses in various areas (especially in the field of interventions in crises), increasing public awareness in the medical field (especially about communicable diseases), and enhancing the people and authorities' sense of responsibility and lack of excessive trust in the cyberspace. ${ }^{27}$

Its psychological achievements also include improving emotional regulation in individuals, identifying individuals' existential capacities in times of crisis, controlling anxious beliefs, improving psychological adjustment, recalling death anxiety, remembering God and seeking refuge in God, enhancing creativity and innovation, individual selfassessment in the field of courage/fear and indifference/ responsibility, measuring human patience and resilience, better understanding of religious beliefs, better understanding of the value of health, distinguishing opportunism and profitand fame-seeking from truth-seeking, human attention to family and friends, empowering empathy, and creating home opportunities and jobs due to home quarantine. ${ }^{28-30}$
In the end, it should be stated that, although it is true according to the Holy Quran that "Whatever benefit comes to you, it is from Allah" (Verse 79, Surah AN-NISA), ${ }^{31}$ God also says elsewhere in the Quran that "It may be that you dislike a thing while it is good for you, and it may be that you love a thing while it is evil for you, and Allah knows, while you do not know" (Verse 216, Surah Al-Baqara). Also, God says "Do not despair of the mercy of Allah; surely Allah forgives the faults altogether; surely, $\mathrm{He}$ is the Forgiving of the Merciful" (Verse 53, Surah Az-Zamar). ${ }^{31}$

According to the abovementioned quotes and also regarding the fact that, in the Holy Quran, it is believed that after each and every difficulty comes relief (Verse 94, Surah Al-Sharh), it can be concluded that these difficult days will definitely pass by, and ease and relief will come back to human beings' lives.

Therefore, it seems that, under such circumstances, the human duty is to deal with the damage caused by COVID-19, as well as to enhance the individuals' scientific and psychological capabilities. So, it is best to focus on opportunities to grow 
and improve the existential capacities in times of crisis. Overall, given that Iran, with a population of 81 million and having a strategic position in the world, faces the most severe economic sanctions imposed, it has been able to cope with the disease and has achieved some success through the empathy between the people and the authorities, resulting in 79379 recoveries and improvements as of May 5, 2020.

\section{About the Authors}

Applied Biotechnology Research Center, Baqiyatallah University of Medical Sciences, Tehran, Iran (Dr Farnoosh); Chemical Injuries Research Center, Systems Biology and Poisonings Institute, Baqiyatallah University of Medical Sciences, Tehran, Iran (Dr Alishiri); Trauma Research Center, Baqiyatallah University of Medical Sciences, Tehran, Iran (Dr Jalali Farahani); Behavioral Sciences Research Center, Life Style Institute, Baqiyatallah University of Medical Sciences, Tehran, Iran (Dr Javidi); Health Research Center, Baqiyatallah University of Medical Sciences, Tehran, Iran (Ms Farhangi); Health Management Research Center, Baqiyatallah University of Medical Sciences, Tehran, Iran (Dr Bahadori) and Health Human Resources Research Center, School of Management and Information Sciences, Shiraz University of Medical Sciences, Shiraz, Iran (Dr Ravangard).

Correspondence and reprint requests to Nasirudin Javidi, Behavioral Sciences Research Center, Life Style Institute, Baqiyatallah University of Medical Sciences, Tehran, Iran (e-mail: nasir.javidi@yahoo.com).

\section{Conflict of Interest Statement}

The authors have no conflicts of interest to declare.

\section{REFERENCES}

1. Dai Y, Hu G, Xiong H, et al. Psychological impact of the coronavirus disease 2019 (COVID-19) outbreak on healthcare workers in China medRxiv. 2020;epub.

2. World Health Organization. Coronavirus disease 2019 (COVID-19): situation report - 51. March 11, 2020. https://www.who.int/docs/defaultsource/coronaviruse/situation-reports/20200311-sitrep-51-covid-19.pdf.sfvrsn= 1ba62e57_10. Accessed November 7, 2020.

3. Cascella M, Rajnik M, Cuomo A, et al. Features, evaluation and treatment coronavirus (COVID-19). StatPearls [Internet]: StatPearls Publishing. Last updated August 10, 2020. https://www.ncbi.nlm.nih.gov/books/ NBK554776/?fbclid=IwAR2b6hvY1reNFrmeQIcznD7wkd5NTj_X19Lbh NkRi6hOwhEDmWocU9qeE_k. Accessed November 7, 2020.

4. DoughAbadi NM, Soleimani A, Javidi N. The effectiveness of grouptherapy intervention on quality of life and hope of women infected with human immunodeficiency virus. Galen Med J. 2016;5(3):139-146.

5. Zhang X, Cai H, Hu J, et al. Epidemiological, clinical characteristics of cases of 19 SARS-CoV-2 infection with abnormal imaging findings. Int J Infect Dis. 2020;94:81-87

6. Peng Q-Y, Wang X-T, Zhang L-N. Findings of lung ultrasonography of novel corona virus pneumonia 21 during the 2019-2020 epidemic. J Intensive Care Med. 2020;epub:1-2.

7. Wu Z, McGoogan JM. Characteristics of and important lessons from the coronavirus disease 2019 (COVID-19) outbreak in China: summary of a report of 72314 cases from the Chinese Center for Disease 24 Control and Prevention. JAMA. 2020;323(13):1239-1242.

8. Javidi N. The effectiveness of emotion-focused couples therapy (EFCT) in improving marital satisfaction and family behavior control. J Appl Couns. 2013;3(2):65-78.

9. Madahi ME, Samadzadeh M. The relationship between emotional intelligence and marital status in sample of college students. Procedia Soc Behav Sci. 2013;84:1317-1320.
10. Jain V, Charlett A, Brown CS. Meta-analysis of predictive symptoms for Ebola virus disease. PLoS Negl Trop Dis. 2020;23(10):e0008799.

11. Tsiligianni I, Kocks JW. Daytime symptoms of chronic obstructive pulmonary disease: a systematic review. NPJ Prim Care Respir Med. 2020;30(1):1-9.

12. Madahi ME, Samadzadeh M, Javidi N. The communication patterns \& satisfaction in married students. Procedia Soc Behav Sci. 2013;84: 1190-1193.

13. Ranjbaran R, Aliakbari M, Javidi N. Predicting the level of colds during the year according to 39 multiple variables of stress, anxiety and depression in women. Int J Med Res Health Sci. 2016;5(9):303-308.

14. Novel CP. The epidemiological characteristics of an outbreak of 2019 novel coronavirus diseases (COVID-19) in China. Zhonghua liu xing bing xue za zhi= Zhonghua liuxingbingxue zazhi. 2020;41(2):145.

15. Javidi N, Soleimani A, Ahmadi Kh SM. Efficacy of emotionally-focused couples therapy (EFCT) to improve family functioning. J Behav Sci. 2013;7(2):181-188.

16. Najafi M, Soleimani AA, Ahmadi K, et al. The effectiveness of emotionally focused therapy on enhancing marital adjustment and quality of life among infertile couples with marital conflicts. Int J Fertil Steril. 2015; 9(2):238.

17. Javidi N, Soleimani A, Ahmadi Kh SM. The effectiveness of training of emotion management strategies according to emotionally focused couple therapy (EFT) to increase sexual satisfaction in couples. J Health Psychol. 2012;1(3):5-18.

18. Javidi N, Bolghanabadi M, Dehghani NM. The effectiveness of couples therapy based on happiness by cognitive-behavior method to increase sexual satisfaction in couples. (Journal of Health Breeze) Family Health 2013;1(4):6-14.

19. Maddahi EM, Khalatbari J, Mobarhan ZG, Samadzadeh M, Keikhayfarzaneh MM, Javidi N. The study of dialectical behavior therapy efficacy on the amount of high school student's depression and suicide thoughts in Rasht City, Iran. J Basic Appl Sci Res. 2012;2(1):466-470.

20. Qu R, Ling Y, Zhang Yh, et al. Platelet-to-lymphocyte ratio is associated with 45 prognoses in patients with coronavirus disease-19. J Med Virol. 2020.

21. Alipour A, Ghadami A, Alipour Z, Abdollahzadeh H. Preliminary validation of the corona disease 48 Anxiety Scale (CDAS) in the Iranian sample. Q J Health Psychol. 2020;8(4) (Series 32).

22. Maddahi ME, Javidi N, Samadzadeh M, Amini M. The study of relationship between parenting styles and personality dimensions in sample of college students. Ind J Sci Technol. 2012;5(9):3332-3336.

23. Ranjbaran R, Aliakbari M, Javidi N. The role of coping styles in predicting job burnout in middle aged by controlling the gender variable. IIOAB J. 2016;7:231-236.

24. Ranjbaran R, Reyshahri AP, Pourseifi MS, Javidi N. The pattern to predict social phobia based on social self-efficacy, shyness and coping style in the secondary school students. Int J Med Res Health Sci. 2016;5(9):275-281.

25. Najafi M, Soleimani A, Ahmadi K, et al. The study of the effectiveness of couple emotionally focused therapy (EFT) on increasing marital adjustment and improving the physical and psychological health of the infertile couples. Iran J Obstet Gynecol Infertil. 2015;17(133):8-21.

26. Soleimani AA, Najafi M, Ahmadi K, et al. The effectiveness of emotionally focused couples therapy on sexual satisfaction and marital adjustment of infertile couples with marital conflicts. Int J Fertil Steril. 2015; 9(3):393.

27. Feng J, Bao Y, Wang Y, et al. Coronavirus vs market: investment opportunities lies underneath the epidemic. 2020. http://dx.doi.org/10.2139/ ssrn.3563059.

28. Lin B, Wu S. COVID-19 (Coronavirus disease 2019): opportunities and challenges for digital health and the internet of medical things in China. OMICS: J Integr Biol. 2020;24(5):231-232.

29. Ahmadi K, Javidi N. The application of cognitive science in military science-a narrative. J Mil Med. 2020;22(1):12-26.

30. Buheji M, Ahmed D. Foresight of coronavirus (COVID-19) opportunities for a better world. Am J Econ. 2020;10(2):97-108.

31. Ali A. Al-Qur'an. Princeton, NJ: Princeton University Press; 2001. 